\title{
In-Home Firearm Access among US Adolescents and the Role of Religious Subculture: Results from a Nationally Representative Study
}

\author{
Forthcoming in Social Science Research
}

\author{
Samuel Stroope, $\mathrm{PhD}$ \\ Affiliation: \\ Department of Sociology, Louisiana State University, Baton Rouge, Louisiana \\ Joshua C. Tom, PhD \\ Affiliations: \\ Department of Sociology, Seattle Pacific University, Seattle, Washington \\ Institute for Advanced Studies in Culture, University of Virginia, Charlottesville, Virginia
}

Address correspondence to:

Samuel Stroope, Department of Sociology, Louisiana State University, 126 Stubbs Hall, Baton Rouge, LA 70803, [sstroope@ @lsu.edu], 225-578-1645 (tel.), 225-578-5102 (fax).

\section{Acknowledgments:}

This secondary analysis was supported by the Council on Research Summer Stipend Program, Office of Research and Development, Louisiana State University. The author thanks the University of North Carolina at Chapel Hill for access to Add Health data. The Add Health program project was designed by J. Richard Udry, Peter S. Bearman, and Kathleen Mullan Harris, and funded by a Grant P01-HD31921 from the National Institute of Child Health and Human Development, with cooperative funding from 17 other agencies. Special acknowledgment is due Ronald R. Rindfuss and Barbara Entwisle for assistance in the original design. Thanks to Lowell Bliss, Michael Crane, and Matt Valasik for productive conversation and comments on an earlier version of this paper.

List of abbreviations: Add Health - National Longitudinal Study of Adolescent Health 


\begin{abstract}
Religious participation is linked to numerous positive safety outcomes for adolescents. Scant attention, however, has been paid to associations between religious participation and safety risks among adolescents. Using data from Add Health $(\mathrm{N}=18,449)$, a nationally representative school-based sample of US adolescents, this study examines the relationship between adolescents' religious affiliation and easy access to firearms at home. Regression analyses adjust for complex sampling design and compare easy firearm access at home among conservative Protestant adolescents to adolescent firearm access in other religious traditions. Conservative Protestant adolescents have a substantially greater likelihood of easy access to a gun at home compared to adolescents of all other major religious traditions in the United States. Recognizing differences in adolescent firearm access between subcultural groups can help public health interventions more effectively identify and address the needs of vulnerable populations. The paper's conclusion considers suggestions for effective policy and programmatic initiatives.
\end{abstract}


Public outcry over the 2012 Newtown shooting helped revive a national debate concerning the destructive potential of guns in the lives of adolescents and children. Religious participation - frequently ignored in this debate - is associated with an array of positive safety outcomes for adolescents; however, in the case of home gun access certain religious characteristics may increase risk. Though few are religion-focused, a number of studies going back to the 1970s have found that adults with Protestant religious affiliation-measured as one undifferentiated group — are more likely than other Americans to own a gun (Celinska 2007; DeFronzo 1979; Dixon and Lizotte 1987; Ellison 1991a, 1991b; O’Connor and Lizotte 1978; Jiobu and Curry 2001; Kleck and Kovandzic 2009). The majority of American Protestants are affiliated with conservative Protestantism (Putnam and Campbell 2010). As the largest religious tradition in the United States, conservative Protestants comprise over one third of American adults. And while Christians have been declining as an overall share of the American population for some time, conservative Protestants have experienced this decline at a much lower rate compared to Mainline Protestants and Catholics. ${ }^{1}$ Scholars have suggested that conservative Protestants are more likely to own a gun compared to the general population (Greeley and Hout 2006). Indeed, a recent analysis of General Social Survey confirms that conservative Protestants have the highest rate of personal handgun ownership compared to other major religious groups in the United States (Yamane 2016).

Yet youth gun access is distinct from adult gun ownership, ${ }^{2}$ and while prior research has shed light on sociodemographic variations in youth gun access (Sorenson and Vittes 2004), the role of religion has been left unexamined. The present study moves beyond studies of religion

\footnotetext{
${ }^{1}$ The decline has been low enough that the conservative Protestant population is actually growing in absolute terms, while Mainline Protestants and Catholics are declining in absolute numbers (Smith and Cooperman 2015).

${ }^{2}$ Adult gun ownership is important for a number of reasons (e.g., completed suicide risk), but youth in-home gun access is distinct in part because there are many adult gun owners who do not have children in the home. Adults who do live with children may also underestimate the level of access children have to their guns.
} 
and guns that largely focus on adult gun ownership and adolescent studies of sociodemographic factors by examining religion, adolescents, and guns - specifically, whether adolescents who are members of the conservative Protestant religious subculture are more likely to have easy access to a gun at home. Known differences in fertility across religious groups underscores the importance of this research for the lives of youth. Conservative Protestants have one of the highest fertility rates of any major religious tradition, either matching or potentially outpacing Catholics $^{3}$ in recent data (Chaves 2011; Westoff and Marshall 2010; Smith and Cooperman 2015)- in other words, a disproportionately greater share of American youth are raised in conservative Protestant households. Using data from The National Longitudinal Study of Adolescent Health (Add Health), this is the first nationally representative study to investigate the relationship between religious subcultures and adolescents' easy access to a firearm at home. Studying the influence of religious subcultures on youths' gun access could aid in developing effective policy and programmatic initiatives, advancing understanding of religious and subcultural impacts on gun safety among young people, and pointing to promising avenues for future research.

\section{Firearms and Young People}

In the last century the predominant causes of child mortality have shifted from infectious diseases to injuries (Guyer et al. 2000). Access to a firearm is an important risk factor in this context. For young Americans, gun injuries are the second most common cause of death (US Centers for Disease Control and Prevention 2014). American children are eleven times more likely to be fatally shot by accident compared to children in other high-income countries (Richardson and Hemenway 2011). Gun injuries are also a common source of hospitalization,

\footnotetext{
${ }^{3}$ Particularly compared to non-Hispanic white Catholics.
} 
morbidity, and disability among children and adolescents (Leventhal, Gaither, and Sege 2014). Most accidental gun injuries to children happen at home, and most unintentional gun fatalities are other-inflicted, with the shooter overwhelmingly likely to be a friend or young family member, such as an older sibling (Hemenway, Barber, and Miller 2010). Guns are also the second most likely method of suicide among adolescents (US Centers for Disease Control and Prevention 2014), and adolescents with a history of suicidality or mental illness have equal likelihood of in-home gun access as other adolescents (Simonetti et al. 2015). In a sample of over thirty-nine injury prevention experts, access to a gun at home was rated as the most serious danger out of major household injury risks for children (Katcher et al. 2006).

Access to guns at home is widespread among youth; in nationally-representative data, one-third of adolescents lived in a home with a gun, and $41 \%$ of those had easy in-home access to and ability to shoot the gun (Simonetti et al. 2015). The majority of gun owners do not store guns in a locked place in the home and are no more likely to store guns safely if children are present (Connor 2005). Completed youth suicides are more likely when a gun is in the home, regardless of whether the gun is locked away or stored separately from ammunition, though increased safety measures reduce some risk (Brent et al. 1991). Injury, morbidity, and mortality findings such as these have led a variety of health organizations to caution the public regarding in-home firearm storage. For example, the America Pediatric Association has maintained that "the absence of guns from children's homes and communities is the most reliable and effective measure to prevent firearm-related injuries in children and adolescents" (American Academy of Pediatrics 2012). Identifying determinants of youth gun access at home is an important public 
health and economic ${ }^{4}$ concern because of links between gun access and increased risk for physical injury, morbidity, disability, and premature death.

\section{Religion and Firearm Access among Adolescents}

Research on religion and adolescent risk behaviors generally finds protective effects for religious involvement (Burdette and Hill 2009; Hill et al. 2009), including protective effects for conservative religious groups (Dew et al. 2008). However, Hill and Cobb $(2011,251)$ note that among young Americans, "religious conservatism may increase the odds of military enlistment—an extremely risky occupational pursuit" (Burdette et al. 2009). Similarly, in the case of access to a firearm at home, there are several reasons to expect that belonging to conservative Protestantism may increase the likelihood of risk.

Guns serve as emotionally-charged symbols of identity and meaning for many gun enthusiasts (Froese and Mencken 2014) — symbols that can become fused with notions of sacredness. Charlton Heston (1998) expressed this sentiment well in a famous National Rifle Association presidential address:

Sacred stuff resides in that wooden stock and blued steel—something that gives the most common man [sic] the most uncommon of freedoms, when ordinary hands can possess such an extraordinary instrument that symbolizes the full measure of human dignity and liberty.

Guns are a positive symbol and identity marker in many conservative Protestant communities, and this is in part why Conservative Protestant youth may be more likely to have in-home gun access. One of the reasons guns are frequently a positive symbol and an identity marker in conservative Protestant communities is a strong individualist tradition within the religious group.

\footnotetext{
${ }^{4}$ Major economic impacts include the health care and social service costs associated with gun injury and deaths.
} 
Conservative Protestant individualism stems from theological and subcultural distinctives within the community (Stark and Glock 1969, 80):

Underlying traditional Christian thought is an image of man [sic] as a free actor, as essentially unfettered by social circumstances, free to choose and thus free to effect his own salvation. This free-will conception of man has been central to the doctrines of sin and salvation. For only if man is totally free does it seem just to hold him responsible for his acts.

With deep historical roots - in the Reformation, American frontier revivalism, pietism, and postrevolution evangelical anti-institutionalism—contemporary conservative Protestantism prizes individual autonomy and self-sufficiency (Hatch 1989). ${ }^{5}$ These tendencies are manifested in conservative Protestants' greater likelihood to desire less government involvement in a variety of life domains (Steensland et al. 2000). They are also manifested for some in the belief that growing secularism will lead to persecution of conservative Christians. In this scenario, a tyrannical state will remove religious liberties, civil liberties, and gun rights (Bivins 2008; Blee and Creasap 2010).

Relatedly, rugged masculinity is another distinctive of the subculture (Gallagher and Wood 2005). Widely popular in conservative Protestant circles, the national best-selling Christian book, Wild at Heart: Discovering the Secret of a Man's Soul, promotes a "wild, dangerous, unfettered," "warrior," "heroic," "alive and free" masculinity freed from the concerns of security and safety (Eldredge 2001, 12, 141, 186, 221). In describing a mother who will not allow her young son to use guns, the book concludes: "That is emasculation" (Eldredge 2001, 65). Defending family against outside threats is a powerful part of this discourse, wherein the responsibility of a man in a correctly-ordered society is the protection of others (Bartkowski

\footnotetext{
${ }^{5}$ These same values and the symbolic dimension of guns likely undergird reasons for gun ownership besides defense, such as hunting and collecting (Froese and Mencken 2014).
} 
2001; Kimmel and Ferber 2000; Wilcox 2004). Gun access in this context is not only

permissible; it may even approach a moral imperative.

In addition to individualism, conservative Protestants are more likely to view Christianity and ideas of "America" as closely fused (Froese and Mencken 2009; Hughes 2003). Such views predict a variety of outcomes including support for the Iraq War and opposition to transracial adoption, interracial marriage, non-Christian immigration, and same-sex marriage (Aho 2013; Perry and Whitehead 2015b; Whitehead and Perry 2015; Perry and Whitehead 2015a; Froese and Mencken 2009). ${ }^{6}$ Part and parcel with the belief that America is a Christian nation is a sacralization of the U. S. Constitution (Fea 2011) and the narrative of the nation's founding. Conservative Protestant luminaries have advanced the idea — also believed by many lay members - that America's first leaders were devout Christians and based the nation's founding documents on the Bible (Smith 2000; Hughes 2009; LaHaye 1994; Marshall and Manuel 1977; Robertson 1986). In this reading of American history divine providence plays an unambiguous role in the creation of the country, paying special notion to the idea that the rights enumerated in the document are derived from natural laws set by God (Kammen 2008; Kozuskanich 2009; Williams 1996).

Under these cultural interpretations the second amendment of the Constitution is granted considerable religious legitimation. Popular Conservative Protestant publications and speakers build a supporting biblical case and emphasize that signers saw bearing arms as a right "which

\footnotetext{
${ }^{6}$ Positive associations with guns among conservative Protestants are also plausibly reinforced by cultural values supporting military service and the idealization of the military mission as having distinct religious undertones. Conservative Protestants not only have high rates of military service (Burdette et al. 2009), their cultural and theological orientations are also associated with the valorization of military service as a virtue (Thomson and Froese 2016). Since the end of World War II Conservative Protestants have had an outspoken presence in the American military at all levels of service (Loveland 1996), likely fueled in no small measure by the character of the United States's Cold War adversary, the U.S.S.R. The secular, Communist nature of the Soviet Union created a politicalreligious intertwining of mission that conservative Protestants increasingly adopted, a "mutually reinforcing relationship between evangelicals and the military" that continues to this day (Loveland 1996, 180).
} 
God gave" (Dickinson 1903; Barton, Cummings, and Wubbels 2014). To attempt deprivation of those rights is to essentially counter the will of God. Thus, the right to self-defense, the ability to defend others, and protection against coercion by others are part of the explicitly religious discourse defending gun rights among Conservative Protestants- indeed, the right to a gun is argued to guarantee other rights, particularly the freedom of religion enumerated in the first amendment (Blackwell 2015; Lio, Melzer and Reese 2008). The latter argument has particular relevance for the religious interests of Conservative Protestants.

Conservative Protestant tendencies toward low social trust and punitive dispositions may also contribute to in-home gun access among youths. Research finds that conservative Protestants have relatively high levels of bonding social capital, low bridging capital, and low generalized trust (Smith 1997; Putnam 2000). A number of studies also find that conservative Protestants tend to see behavior in relatively black and white terms, have strong disapproval of various crimes and acts of deviance, and favor harsh punishments for offenders (Ellison, Burr, and Mccall 2003; Bartkowski and Ellison 2009; Schieman et al. 2006; Grasmick, Bursik, and Kimpel 1991; Unnever, Cullen, and Applegate 2005). Conservative Protestants and those with conservative religious beliefs tend to emphasize individual choice and make dispositional, rather than situational, attributions for wrongdoing (Spilka, Shaver, and Kirkpatrick 1985, 3; Grasmick et al. 1992; Grasmick and McGill 1994). For conservative Protestants, this can involve a tendency to reduce the sources of behavior to "sinful" choices and a resistance to recognizing structural influences. Additionally, conservative Protestants may frequently draw upon select Old Testament imagery of a wrathful and retributive God in justifying harsh and decisive reactions (Froese and Bader 2010; Bader et al. 2010; Ellison 1991b; Emerson, Smith, and Sikkink 1999). This background suggests that a combination of conservative Protestant distinctives regarding 
social encapsulation, social trust, attributions, and punishment may inspire the view that guns are an acceptable and normal means of defense against potential wrongdoers. Adolescents surrounded by such norms among family, church members, and community members can infer or be actively taught that they may need to access a gun for deterrence or defense.

Social tension with secular institutions may also contribute to gun access. Conservative Protestants tend to have an oppositional stance toward secular institutions and have less regard for information provided by these institutions, which may include public safety recommendations regarding firearms. Maintaining tension with social institutions has been a hallmark of contemporary conservative Protestantism in America (Smith et al. 1998)_including a tendency to be skeptical of secular education and scientific research (Sikkink and Hill 2005; Sherkat 2011; Stroope, Franzen, and Uecker 2015; Berkman, Pacheco, and Plutzer 2008; Deckman 2002; Ellison and Musick 1995; Mazur 2004; J. D. Miller, Scott, and Okamoto 2006; Plutzer and Berkman 2008; Scott 2004; Darnell and Sherkat 1997; Sherkat and Darnell 1999; Sikkink 1999; Johnson, Scheitle, and Ecklund 2016). This tension may come from the "institutional reputation" that mainstream educational and scientific institutions are involved in liberalizing and secularizing society (Gross and Fosse 2012; Wuthnow 1988, 154-72). Many conservative Protestants place trust in God in opposition to confidence in science, and view scientific knowledge as a form of sinful hubris (Hood, Hill, and Williamson 2005; Noll 1994). For these and other reasons, information sources such as television programs, radio stations, news media, magazines, books, and experts are labeled by conservative Protestants as either in line with a Christian worldview and trustworthy, or unchristian and untrustworthy (Land 2007). Additionally, some scholars argue that the combination of conservative Protestants' theological or moral certainty and tension with mainstream society hampers open and systematic thinking 
about the multifaceted nature of human behavior (Hood, Hill, and Williamson 2005). For example, rather than consider structural explanations of human behavior, many conservative Protestants reduce behavior to beliefs about God's mysterious will, sinful human choices, or the decline of the nuclear family ${ }^{7}$ (Emerson, Smith, and Sikkink 1999).

As conservative Protestants are skeptical of many aspects of scientific information, they may also tend to leave behind health and safety precautions such as those provided by pediatricians, health professionals, and social science researchers (Sherkat 2011, 2016). Research shows that storing a gun at home is more likely to result in a family member or friend being shot than in affording protection from an intruder (Kellermann and Reay 1986; Hemenway 2011; Lee et al. 1991). Health and safety professionals and organizations have increasingly communicated concern to the public regarding keeping a gun at home and storage habits. A number of organizations such as the American College of Physicians and the American Academy of Pediatrics advise pediatricians and other doctors to counsel parents and other patients regarding gun removal, storage, and safety risks (Olson, Christoffel, and O’Connor 2007).

In addition to relatively low confidence in public safety information, conservative Protestants may have relatively low exposure to such information due to relatively insular social networks (Sherkat 2010, 2011). Conservative Protestants have comparatively high levels of social network closure. ${ }^{8}$ The structure of social networks influences people's access to and retention of information (Carley 1986; Smith-Lovin and McPherson 1993; McPherson, SmithLovin, and Cook 2001). Conservative Protestants are known to privilege social ties with

\footnotetext{
${ }^{7}$ Emerson et al. (1999: 402) note that conservative Protestants "often recognize the importance of micro structures, such as family and church" and underscore the importance of healthy interpersonal relationships such as those in families.

${ }^{8}$ They have relatively high network closure across various social domains including family, congregational life, job, and local community (Wuthnow 2002; Iannaccone 1994; Beyerlein and Hipp 2005). Controlling for sociodemographics and religious service attendance, Mencken, Bader and Embry (2009) find that conservative Protestants have lower levels of general social trust, neighbor trust, and coworker trust.
} 
likeminded adherents and caution against bonds with non-adherents for fear that these will draw people away from a moral and faith-filled life (Sherkat and Ellison 1997; Ammerman 1987). This network insularity impedes the cultivation of new ties and limits the utility of existing network ties in connecting to novel information. ${ }^{9}$ If individuals gain access to information beyond their networks, the distrust for external sources of information fostered by closed networks is known to inhibit absorption of and use of the information (Reinholt, Pedersen, and Foss 2008). In sum, due to social insularity and a negative orientation towards secular knowledge and institutions, conservative Protestant parents may be less likely to encounter, trust, and adopt mainstream scientific information and safety recommendations regarding guns in the home.

The above conservative Protestant distinctives may have a variety of behavioral manifestations. Parents may frequently talk about household guns in a positive manner and so store guns with fewer restrictions; and youth likely have heightened interest in gun culture and usage. We hypothesize that conservative Protestant adolescents will have greater likelihood of easy access to a gun at home compared to adolescents of all other major religious traditions in the United States.

\section{Gun Debates in Conservative Protestant Popular Discourse}

Though conservative Protestants are known for their support of gun ownership and opposition to many restrictions on guns, debates exist in the popular discourse of the subculture. A typical argument in favor of gun rights is articulated by radio host Bethany Blankley (2016), who argues that "the "Right to Bear Arms" is a commitment and obedience to protecting one's right to life, an inalienable right, that God requires be protected from harm... According to the

\footnotetext{
${ }^{9}$ Religious social network closure is associated with limited weak ties and diminished trust toward those not in the network (Pescosolido and Georgianna 1989; Sandomirsky and Wilson 1990; Sherkat and Wilson 1995; Welch, Sikkink, and Loveland 2007; Simpson 2006).
} 
Bible, men are required to protect themselves, their families, their homes, their possessions, and if they choose not to, they are negligent." However, a vocal minority argues that such sentiments run counter to their faith tradition, contending that biblical injunctions against violence and killing are more binding (Miller 2013; Schenck 2016).

These disagreements often stem from discordant views on the relationship of Christianity to the United States. Blankley (2016) articulates a common view that connects biblical law to the construction of the American Constitution and its enumerated rights when she argues that

God's definition of the right to life and one's right to protect it is clear throughout both the Old and New Testament of the Bible. God created laws and government to restrain evil and promote that which is good. The Ten Commandments were the initial guide for right conduct, but numerous civil and criminal laws were enacted and enforced through Moses and the court system he established with judges. These laws became the basis for Western law, including laws governing self-defense, personal injury, property rights, and much more.

The right to bear arms is therefore considered a divinely-inspired piece of American law.

The views of those who favor greater gun restrictions often appeal to a different perspective on how Christians should conceive of the United States, typified by writer Sharon Hodde Miller (2013) in an editorial for Christianity Today:

While the gun control debate is integrally linked with the U.S. Constitution, I am writing as a Christian first and an American second. As a citizen of this country, the Constitution is indeed an authoritative document in my life, but its authority is not ultimate. I am first beholden to God. So when the laws of the land are perpetuating violence and destruction, as I believe they are in this case, the Christian's position cannot be neutral.

Such views reject any strict parallels drawn between American law and divine law.

These debates can also run deep into theological questions of the nature of social evils and the extent to which they can be deterred by human efforts. In the wake of the mass shooting 
in Aurora, Colorado in 2013, Christianity Today editor Mark Galli cautioned "we are kidding ourselves if we think we have within our national grasp an educational or psychological or political solution to evil" (Gibson 2012). Yet in the same magazine a dissenting view by Sharon Miller (2013) offered a different view, suggesting that that "As long as there are broken humans on earth, there will be violence and death. However, we cannot hide behind this spiritual reality as an excuse for inaction. Sinful people kill people, but guns sure do make it a lot easier." Even among Christians who share religious beliefs about evil there is a diversity of views on how that evil is best approached.

Other distinctly religious arguments exist in the popular discourse on guns among conservative Protestants. Those skeptical of gun ownership have cited the Christian teaching to not live in fear as reason to be cautious of possessing weapons. (Christianity Today 1999; Piper 2015, 201). Indeed, under these auspices the pro-life platform is sometimes expanded beyond abortion to include gun control and recommendations against personal gun ownership. Antiabortion activist Rob Schenck's pivot away from pro-gun stances in 2013 is a good example:

It's a pro-life question, and it's a deeply moral question, and it's, even for me, it's a theological question... I've made the decision not to own a weapon. There's a lot of reasons for that. One is, I think it does create an ethical crisis for a Christian. Secondly, I don't necessarily trust myself, and maybe more of us would be better off to question what we will do in the heat of anger, fear, or God forbid, depression" (NPR Staff 2015).

For these conservative Protestants, the religious-ethical implications of committing violence against another human being, even in the course of self-defense or defense of others, compel them to reject gun ownership. Although this inner subcultural discord is rarely in the spotlight, the debate does exist- even if the gun restriction voices remain less powerful and visible than their pro-gun counterparts. 


\section{Methods}

Above, we hypothesized that conservative Protestant youth will have greater odds of access to a gun at home compared to youth of other major religious traditions. To assess this hypothesis, we use data from wave one of Add Health. Add Health used a sampling frame from which 80 high schools were selected and matched 52 feeder middle schools. Stratification was by region, urbanicity, racial composition, and size of school. Over 90,000 students were surveyed and a representative subsample of $7^{\text {th }}-12^{\text {th }}$ graders was selected for in-depth in-home surveys, resulting in a nationally representative school-based sample of 20,745 adolescents (79\% of eligible participants). In addition, a parent (usually the mother) was interviewed. Additional information on the Add Health survey is available at www.cpc.unc.edu/projects/addhealth. ${ }^{10}$

After dropping 1,875 cases without a sampling weight, an additional 114 cases had missing values on the dependent variable. After applying these filters, all variables with the exception of family income ${ }^{11}$ had less than $1.7 \%$ of cases missing, which were handled using a complete case strategy. This strategy resulted in a final analytic sample size of 18,449 . In the results that follow, descriptive and regression analyses are weighted and apply complex analysis procedures in SAS 9.4 which take into account the strata and clustering of Add Health's complex sampling design.

Add Health interviewers asked adolescents, "Is a gun easily available to you in your home?"12 Binary logistic regression is used to analyze the odds of adolescents' easy gun access

\footnotetext{
${ }^{10}$ Wave I is used because Wave II was only one year later and because of attrition and sample restrictions at Wave II.

${ }^{11}$ Missing cases for family income are coded as the mean value of the family income variable. As a safeguard, regression models also control for an indicator for a missing value on income.

${ }^{12}$ This is a measure that likely goes beyond assessing gun ownership. Though we have no separate measure of parental gun ownership, this measure of teen-reported in-home gun access is substantively different than a general measure of adult personal handgun ownership as analyzed in studies of religion and gun ownership (e.g., Yamane
} 
at home. To measure religious affiliation, a standard coding scheme ${ }^{13}$ is used that accounts for the largest religious traditions in the United States (Steensland et al. 2000) and was guided by prior Add Health research (Pearce and Haynie 2004): conservative Protestant (referent), Mainline Protestant, Black Protestant, Catholic, “other” religions ${ }^{14}$, and religiously unaffiliated. The multivariate regression analysis controls for a variety of salient background characteristics: gender, age, race/ethnicity, residence in the South, urbanicity, family structure (lives with two biological/adoptive parents), family income, and parental education. Parental education is measured as the highest education of any parent. Table 1 shows descriptive statistics for study variables.

$* * *$ Table 1 about here***

\section{Results}

Overall, 24.4\% of adolescents reported having easy access to a gun at home (Table 1). As seen in Figure 1, 36.7\% of conservative Protestant adolescents had easy access to a gun in the home, by far the highest percentage for any religious tradition. Over a quarter $(27.3 \%)$ of mainline Protestant adolescents report easy access, followed by the religiously unaffiliated (20.9\%), Catholics (19\%), members of other religious groups (18.8\%), and Black Protestants $(13.3 \%)$

2016). There are two main reasons for this. First, the teen measure is not limited to ownership of a personal handgun. Second, adult gun ownership is important for a number of reasons (e.g., completed suicide risk), but youth in-home gun access is distinct in part because there are many adult gun owners who do not have children in the home. Third, parental perception of the security of their firearms may not match their children's perception. Directly asking teens to assess their access to in-home firearms can sidestep measurement bias from potentially misplaced parental confidence in the safe storage of family firearms.

${ }^{13}$ The following are examples of major denominational groups in the utilized scheme's Protestant religious traditions. Conservative Protestantism includes Assemblies of God, Baptist, and Pentecostal denominations. Black Protestantism includes African Methodist Episcopal Church, African Methodist Episcopal Zion Church, and Christian Methodist Episcopal Church denominations. Mainline Protestantism includes Congregational, Episcopal Church, and Presbyterian denominations.

${ }^{14}$ Due to small cell sizes, we collapse Jews into "other." Analyses (not shown) including Jews yielded similar results and Jewish affiliation was inversely associated with gun access. In the Steensland et al. scheme, Jewish is a separate category. 
$* * *$ Figure 1 about here***

Conservative Protestant youth remain more likely to have gun access compared to youth of all other religious traditions in multivariate models that control for important background characteristics (Table 2). ${ }^{15}$ Compared to conservative Protestants, the odds of gun access were 17\% lower for mainline Protestants, 50\% lower for Black Protestants, $40 \%$ lower for Catholics, $44 \%$ lower for other religious adherents, and $37 \%$ lower for the religiously unaffiliated. Another comparison focused on differences in the predicted probability of easy gun access at home (Figure 2). Illustratively, a 16 year old white male conservative Protestant in the rural South with a single parent, average parental income, and high school graduation as the highest parental education had a predicted probability of .26 for easy gun access at home. If that same individual were religiously unaffiliated, he would have a predicted probability of .18, a drop in the predicted probability of .08 - a substantial reduction.

$$
\begin{aligned}
& * * * \text { Table } 2 \text { about here } * * * \\
& * * * \text { Figure } 2 \text { about here*** }
\end{aligned}
$$

\section{Supplementary analyses}

In ancillary analyses, the following variables were controlled and none changed the study conclusions nor mediated religious affiliation differences: respondent biblical inerrancy, parental biblical inerrancy, respondent religious attendance, parental religious attendance, respondent religious salience, respondent prayer frequency, and parental military service. The religious affiliation p-values generally became smaller in these ancillary models. Additionally, religious

\footnotetext{
${ }^{15}$ As indicated by Akaike information criterion, Schwartz Criterion, and log likelihood statistics, this model has superior model fit compared to a model without religious traditions.
} 
affiliation by attendance interactions were tested and no statistically significant interactions were observed. ${ }^{16}$ We also found no significant interactions of religious affiliation by urbanicity.

\section{Discussion}

Access to a firearm at home is widespread among adolescents in the United States and is associated with increased risk of mortality, morbidity, and disability. The current study suggests that religious subculture plays an important role in widespread youth firearm access.

Specifically, this study is the first to show that adolescents affiliated with conservative Protestantism have a significantly greater likelihood of easy access to a gun at home compared to adolescents of all other major religious traditions in the United States. This finding complicates research on the effects of religion on adolescent health and safety risk factors, which generally finds protective effects of religious involvement and conservative religious groups (Burdette and Hill 2009; Hill et al. 2009; Dew et al. 2008; Manglos 2013; Adamczyk and Felson 2012; Adamczyk and Palmer 2008; Wallace and Forman 1998; Harker 2001; Borowsky, Ireland, and Resnick 2001; Regnerus 2003). This study also adds to a growing body of research showing the importance of religious subcultures for life chances and the unfavorable influence of conservative Protestantism and conservative religious beliefs for a number of outcomes, extending this literature to the arena of an important health and safety risk factor (Cline and Ferraro 2006; Darnell and Sherkat 1997; Fitzgerald and Glass 2008; Glass and Jacobs 2005; Keister 2008; Massengill 2008; Sherkat and Darnell 1999; Emerson and Smith 2000; Ellison, Burr, and Mccall 2003; Sherkat 2010, 2012; Stroope, Franzen, and Uecker 2015; Uecker 2014; Lehrer 1999).

\footnotetext{
${ }^{16}$ Catholic and Mainline Protestant interactions with religious attendance were marginally significant $(\mathrm{p}<.10)$.
} 
Independent from structural explanations of adolescent in-home gun access—which link gun access to influences such as region of residence, socioeconomic status, and family structure - the current study demonstrates that gun access is correlated with conservative Protestant affiliation even after statistically adjusting for an array of structural characteristics. These findings take on additional importance given that conservative Protestants have some of the highest fertility rates of any major religious group and a high proportion of American youth grow up in conservative Protestant homes (Chaves 2011; Smith and Cooperman 2015; Westoff and Marshall 2010).

In the context of the ongoing national discussion surrounding the impact of gun violence on adolescents and children, the overall high levels of in-home gun access and elevated levels of access within particular subgroups are a substantial impediment to reducing gun-related mortality, morbidity, and disability among American young people. In the absence of stronger public policies and social norms surrounding gun safety, young people's in-home gun access will continue to be largely assigned to voluntary adherence to gun storage and safety practices among families and young people.

Drawing from research in the social scientific study of religion, the current study develops arguments suggesting that subcultural distinctives drive the heightened access to a gun at home among conservative Protestant adolescents. This does not suggest that conservative Protestants devalue the safety and health of adolescents and children; rather, the risk of gun access may result because of distinctive characteristics in conservative Protestantism: (1) A rugged individualist tradition that prizes self-sufficiency and protection of the family (Emerson, Smith, and Sikkink 1999), (2) a tendency to sacralize America's founding documents including the second amendment (Hughes 2003), (3) relatively punitive attitudes and low levels of social 
trust (Ellison, Burr, and Mccall 2003; Bartkowski and Ellison 2009; Schieman et al. 2006; Smith 1997), (4) tension with secular institutions resulting in greater skepticism toward information provided by these institutions, such as firearm safety information (Smith et al. 1998; Sherkat 2011), and (5) less exposure to and inclination for absorbing public health information on firearms due to relatively insular social networks (Sherkat 2011). The confluence of these subcultural distinctives promote guns as a positive symbol and identity marker among conservative Protestants and mute cautionary voices. As with other values and norms, these positive views are likely reinforced by family, church friends and leaders, and others in the community (Smith 2003; Stroope 2012, 2011a). Some of the behavioral manifestations of these distinctives may include parents storing guns with fewer restrictions and heightened interest in guns among young conservative Protestants.

Other differences in gun access between religious traditions deserve mention. After conservative Protestants, Mainline Protestant adolescents are the most likely to have easy access to a gun at home. This finding aligns with recent General Social Survey data which show that Mainline Protestants are second (17\%) only to conservative Protestants (20\%) in personal handgun ownership (Yamane 2016). Relatedly, Froese and Mencken (2009) find that Mainline Protestants are in some instances on par with conservative Protestants in support for Christian nationalism (i.e., believing that Christianity and America are closely fused). While conservative Protestantism is distinguished by its especially strong and rugged individualism, Mainline Protestantism also has a robust, if less distinctive, tradition of freedom and individualism, elements in "a set of liberal values" long championed by Mainline Protestant denominations (Demerath 1995, 460). Many conservative and Mainline Protestant religious bodies share a common religious and cultural heritage (Finke and Stark 2005), lay Mainline Protestants tend to 
hold more conservative attitudes compared to their clergy and denominational elites (Edgell 2006; Olson 2000; Fowler 1989), and it is the more evangelical and conservative congregations within Mainline Protestantism which have been growing or at least declining less rapidly (Stark and Finke 2000). ${ }^{17}$ Indeed, in Yamane's (2016) multivariate analysis of personal handgun ownership, the inclusion of theological conservatism brings out the difference between Mainline and conservative Protestants. In other words, the gun ownership difference between these groups is statistically masked until theological conservatism is measured. All in all, whether through Mainline Protestantism's individualist impulses, its internal theological diversity, or growing conservatism, there are several potential explanations for Mainline Protestant youth gun access worthy of further inquiry.

Catholics, by way of comparison, are less likely than Protestants to hold punitive attitudes, are less prone to the style of individualism associated with positive attitudes about guns, and some Catholics have connected pro-life attitudes with gun control (Bjarnason et al. 2005; Froehle and Gautier 2000). The Catholic Church has an official stance on abortion, euthanasia, and capital punishment, whereas it has no official stance on guns. Some Catholics argue that gun control should be one of the issues that are part of a "consistent pro-life ethic" stance, however this is a relatively recent development in the conversation (Goodstein 2013).

Several policy implications emerge from this study's findings. First, this research has identified a vulnerable population that could benefit from focused firearm safety programs. Previous studies have found that congregation-sponsored health programming can be valuable in serving vulnerable groups (Campbell et al. 2007; Peterson, Atwood, and Yates 2002; Adamczyk and Felson 2012; Trinitapoli, Ellison, and Boardman 2009). In particular, parental education

\footnotetext{
${ }^{17}$ Evangelical inclinations are also diffusing within a number of Mainline Protestant denominations (Ellingson 2007).
} 
regarding safe gun storage or removal, and youth programs in conservative Protestant congregations, schools, and youth organizations, could be developed. Additionally, public health efforts to reduce adolescent gun-related mortality, morbidity, and disability could be enhanced by focusing on key mechanisms such as social and informational encapsulation that are potential drivers of the relationship between conservative Protestantism and adolescents' easy access to guns at home. One possibility — addressing parents, local programs, and bridging informational encapsulation — would be to reach out to key leaders who could influence congregations and social networks from within. Whereas pastors would be an obvious focus, outreach to lay leaders may be especially effective since conservative Protestant lay leaders have substantial influence within congregations (Bean and Martinez 2015). Effective outreach to conservative Protestant contacts may come from organizations tied to health promotion and evidence-based standards, yet which have credible reputations among many conservative Protestants. ${ }^{18}$

Re-orienting and tailoring material and messaging toward core values of conservative Protestants may increase the likelihood of overcoming out-group skepticism (Gollust, Niederdeppe, and Barry 2013). Indeed, conservative Protestants have developed material such as Christian education curricula promoting topics ranging from environmentalism to evolution, rooting material in core evangelical cultural and theological language and values (Zylstra 2013). Gun safety education coming from within the existing conservative Protestant subculture, rooted in themes of personal responsibility, family safety, the body as a "temple of God," and following laws of the land may be effective. A national evangelical gun safety network focused on serving

\footnotetext{
${ }^{18}$ One example is $4-\mathrm{H}$, the leading youth development organization in the United States. Many 4-H programs across the country employ an agent focused on outdoor sports such as shooting and who engage in firearm safety programming. One entity embraced by many conservative Protestants (Stanojevich 2013) that could also potentially promote more responsible gun ownership is the National Rifle Association.
} 
key influencers and local chapters could help house and sustain efforts. ${ }^{19}$ One issue that arises in educational interventions is that recent studies have revealed little evidence for the effectiveness of educational programs (e.g., "Eddie Eagle") directed at youth firearm attitudes and behaviors, and some programs may actually increase unfavorable behaviors by heightening interest in guns (National Research Council 2005). That said, educational programs have been one of a host of factors that have contributed to improved safety behaviors among adults in other contexts (e.g., seatbelt use) and the effectiveness of these educational approaches may be applicable to parents' choice to have a gun in the home and safer storage practices (Hemenway 2001). In addition to holding the potential to modify personal safety behavior, education programming may initiate and reinforce social norms around behaviors and foster public support for larger-scale policy initiatives that are known to have a substantial impact on behavior (Jansson et al. 2006; Berfenstam 1995; Gielen, Sleet, and Green 2006).

A number of promising research avenues follow from this study. First, similar to other research on religious subcultural effects (Stroope 2011b; Darnell and Sherkat 1997; Sherkat 2011; Keister 2008; Emerson, Smith, and Sikkink 1999), future firearm research should measure and model the mechanisms through which conservative Protestantism impacts in-home gun access. As outlined in this study, future research should consider the role of attitudes, information, and social networks for producing beliefs and behaviors regarding firearm access. The current study shows that religious affiliation is the driver of gun access rather than religious beliefs. This differs from research on other outcomes, which has shown that beliefs matter more than affiliation. The current study's findings suggests that future work should not too readily move away from studying the impact of historically meaningful religious traditions (Scheitle and Adamczyk 2010). Second, the Add Health survey did not gather information about the manner in

\footnotetext{
${ }^{19}$ Organizations such as the Evangelical Environmental Network (creationcare.org) could provide a template.
} 
which guns were stored in adolescents' homes, a contributing factor in outcomes such as adolescent suicide (Shenassa et al. 2004). Subsequent analyses using more comprehensive data could build on this study by comparing adolescent access to unlocked and loaded firearms across religious subcultures and other markers of religious involvement. Third, data limitations prevented measurement of political ideology, which future work should assess. Finally, the growing homeschooling movement is popular among conservative Protestant families (Bauman 2001; Thomson and Jang 2016). Like many studies of adolescents, this research did not include homeschooled adolescents. Future research should examine the importance of homeschooling in potentially amplifying relevant conservative Protestant beliefs, network insularity, and access to a gun at home.

Despite the need for more research, the present study has advanced knowledge regarding a global measure of adolescents' in-home gun access, a phenomenon linked to causes of death, morbidity, and disability in the lives of adolescents and children. These findings join with other research (Hill et al. 2006) indicating that our understanding of the connections between religion and health behaviors and risk factors would be substantially advanced by closer attention to religious subcultures. More broadly, this study highlights a major link between culture and risk factors. Research has sought to locate (at times elusive) social and cultural influences that increase adolescents' exposure to risk factors. Conservative religious subcultures-a widespread and institutionally-based source of gun access — offer an important avenue of inquiry going forward. 


\section{References}

Adamczyk, Amy, and Jacob Felson. 2012. "The Effect of Religion-Supported Programs on Health-Related Behaviors in Adolescence." Review of Religious Research 54 (4): 46997.

Adamczyk, Amy, and Ian Palmer. 2008. "Religion and Initiation into Marijuana Use: The Deterring Role of Religious Friends." Journal of Drug Issues 38 (3): 717-41.

Aho, James. 2013. "Christian Heroism and the Reconstruction of America." Critical Sociology 39 (4): 545-60.

American Academy of Pediatrics. 2012. "Firearm-Related Injuries Affecting the Pediatric Population: Council on Injury, Violence, and Poison Prevention Executive Committee." Pediatrics 130 (5): e1416-23.

Ammerman, Nancy Tatom. 1987. Bible Believers: Fundamentalists in the Modern World. New Brunswick: Rutgers University Press.

Bader, Christopher D., Scott A. Desmond, F. Carson Mencken, and Byron R. Johnson. 2010. "Divine Justice: The Relationship Between Images of God and Attitudes Toward Criminal Punishment." Criminal Justice Review 35 (1): 90-106.

Bartkowski, John P. 2001. Remaking the Godly Marriage: Gender Negotiation in Evangelical Families. New Brunswick, NJ: Rutgers University Press.

Bartkowski, John P., and Christopher Ellison. 2009. "Conservative Protestants on Children and Parenting." In Children and Childhood in American Religions, edited by Don S.

Browning and Bonnie J. Miller-McLemore, 42-55. New Brunswick, New Jersey: Rutgers University Press.

Barton, David, Brad Cummings, and Lance Wubbels. 2014. The Founder's Bible: The Origin of the Dream of Freedom. 2nded. Newbury Park, CA: Shiloh Road Publishers.

Bauman, Kurt J. 2001. "Home Schooling in the United States: Trends and Characteristics." Working Paper Series No. 53. Washington, DC: US Census Bureau. http://epaa.asu.edu/ojs/index.php/epaa/article/view/305.

Bean, Lydia, and Brandon C. Martinez. 2015. "Sunday School Teacher, Culture Warrior: The Politics of Lay Leaders in Three Religious Traditions." Social Science Quarterly 96 (1): 133-47.

Berfenstam, R. 1995. "Sweden's Pioneering Child Accident Programme: 40 Years Later." Injury Prevention 1 (2): 68-69.

Berkman, Michael B., Julianna Sandell Pacheco, and Eric Plutzer. 2008. "Evolution and Creationism in America's Classrooms: A National Portrait." PLoS Biology 6 (5): 920-24.

Beyerlein, Kraig, and John R. Hipp. 2005. "Social Capital, Too Much of a Good Thing? American Religious Traditions and Community Crime.” Social Forces 84 (2): 995-1013.

Bivins, Jason. 2008. Religion of Fear: The Politics of Horror in Conservative Evangelicalism. Oxford; New York: Oxford University Press.

Bjarnason, Thoroddur, Thorolfur Thorlindsson, Inga D. Sigfusdottir, and Michael R. Welch. 2005. "Familial and Religious Influences on Adolescent Alcohol Use: A Multi-Level Study of Students and School Communities." Social Forces 84 (1): 375-90.

Blankley, Bethany. 2016. "What the Bible Says About the Second Amendment." Charisma News. May 26. http://www.charismanews.com/politics/opinion/57429-what-the-biblesays-about-the-second-amendment.

Blee, Kathleen M., and Kimberly A. Creasap. 2010. "Conservative and Right-Wing Movements.” Annual Review of Sociology 36 (1): 269-86. 
Borowsky, Iris Wagman, Marjorie Ireland, and Michael D. Resnick. 2001. "Adolescent Suicide Attempts: Risks and Protectors." Pediatrics 107 (3): 485-493.

Brent, David A., Joshua A. Perper, Christopher J. Allman, Grace M. Moritz, Mary E. Wartella, and Janice P. Zelenak. 1991. "The Presence and Accessibility of Firearms in the Homes of Adolescent Suicides: A Case-Control Study.” JAMA 266 (21): 2989-2995.

Burdette, Amy M., and Terrence D. Hill. 2009. "Religious Involvement and Transitions into Adolescent Sexual Activities.” Sociology of Religion 70 (1): 28-48.

Burdette, Amy M., Victor Wang, Glen H. Elder, Terrence D. Hill, and Janel Benson. 2009. "Serving God and Country? Religious Involvement and Military Service among Young Adult Men.” Journal for the Scientific Study of Religion 48 (4): 794-804.

Campbell, Marci Kramish, Marlyn Allicock Hudson, Ken Resnicow, Natasha Blakeney, Amy Paxton, and Monica Baskin. 2007. "Church-Based Health Promotion Interventions: Evidence and Lessons Learned." Annual Review of Public Health 28: 213-234.

Carley, Kathleen. 1986. "An Approach for Relating Social Structure to Cognitive Structure." Journal of Mathematical Sociology 12 (2): 137-189.

Celinska, Katarzyna. 2007. "Individualism and Collectivism in America: The Case of Gun Ownership and Attitudes toward Gun Control." Sociological Perspectives 50 (2): 229-47.

Chaves, Mark. 2011. American Religion: Contemporary Trends. Princeton, NJ: Princeton University Press.

Christianity Today. 1999. "In Guns We Trust," October 4. http://www.christianitytoday.com/ct/1999/october4/in-guns-we-trust-fear-idolatry.html.

Cline, Krista, and Kenneth F. Ferraro. 2006. "Does Religion Increase the Prevalence and Incidence of Obesity in Adulthood?” Journal for the Scientific Study of Religion 45 (2): 269-281.

Connor, Susan M. 2005. "The Association between Presence of Children in the Home and Firearm-Ownership and-Storage Practices." Pediatrics 115 (1): e38-e43.

Darnell, Alfred, and Darren E. Sherkat. 1997. "The Impact of Protestant Fundamentalism on Educational Attainment.” American Sociological Review 62 (2): 306-15.

Deckman, Melissa. 2002. "Holy ABCs! The Impact of Religion on Attitudes about Education Policies." Social Science Quarterly 83 (2): 472-487.

DeFronzo, James. 1979. "Fear of Crime and Handgun Ownership." Criminology 17 (3): 331-40.

Demerath, N. J. 1995. "Cultural Victory and Organizational Defeat in the Paradoxical Decline of Liberal Protestantism.” Journal for the Scientific Study of Religion 34 (4): 458-69.

Dew, Rachel Elizabeth, Stephanie S. Daniel, Tonya D. Armstrong, David B. Goldston, Mary Frances Triplett, and Harold G. Koenig. 2008. "Religion/spirituality and Adolescent Psychiatric Symptoms: A Review." Child Psychiatry and Human Development 39 (4): 381-98.

Dickinson, John. 1903. "Letter to the Society of Fort St. David's." In Letters from a Farmer in Pennsylvania, edited by R. T. H. Halsey, xlii. New York, New York: The Outlook Company.

Dixon, Jo, and Alan J. Lizotte. 1987. "Gun Ownership and the 'Southern Subculture of Violence."” American Journal of Sociology 93 (2): 383-405.

Edgell, Penny. 2006. Religion and Family in a Changing Society. Princeton University Press. Eldredge, John. 2001. Wild at Heart: Discovering the Passionate Soul of a Man. Nashville, Tennessee: Thomas Nelson. 
Ellingson, Stephen. 2007. The Megachurch and the Mainline: Remaking Religious Tradition in the Twenty-First Century. Chicago: University Of Chicago Press.

Ellison, Christopher G. 1991a. "Southern Culture and Firearms Ownership." Social Science Quarterly 72 (2): 267-83.

. 1991b. "An Eye for an Eye? A Note on the Southern Subculture of Violence Thesis." Social Forces 69 (4): 1223-39.

Ellison, Christopher G., Jeffrey A. Burr, and Patricia L. Mccall. 2003. "The Enduring Puzzle of Southern Homicide Is Regional Religious Culture the Missing Piece?" Homicide Studies 7 (4): 326-52.

Ellison, Christopher G., and Marc A. Musick. 1995. "Conservative Protestantism and Public Opinion toward Science." Review of Religious Research 36: 245-262.

Emerson, Michael O., and Christian Smith. 2000. Divided by Faith: Evangelical Religion and the Problem of Race in America. Oxford University Press, USA.

Emerson, Michael O., Christian Smith, and David Sikkink. 1999. "Equal in Christ, but Not in the World: White Conservative Protestants and Explanations of Black-White Inequality." Social Problems 46 (3): 398-417.

Fea, John. 2011. Was America Founded as a Christian Nation? Louisville, Ky.: Westminster John Knox Press.

Finke, Roger, and Rodney Stark. 2005. The Churching of America, 1776-2005: Winners and Losers in Our Religious Economy, Revised and Expanded Edition. Revised. New Brunswick, NJ: Rutgers University Press.

Fitzgerald, Scott T., and Jennifer L. Glass. 2008. "Can Early Family Formation Explain the Lower Educational Attainment of US Conservative Protestants." Sociological Spectrum 28 (5): 556-77.

Fowler, Robert Booth. 1989. Unconventional Partners: Religion and Liberal Culture in the United States. Grand Rapids, Mich.: W.B. Eerdmans Pub. Co.

Froehle, Bryan T., and Mary L. Gautier. 2000. Catholicism USA: A Portrait of the Catholic Church in the United States. Vol. 1. Maryknoll, New York: Orbis Books.

Froese, Paul, and Christopher D. Bader. 2010. America's Four Gods: What We Say About God and What That Says About Us. New York: Oxford University Press.

Froese, Paul, and F. Carson Mencken. 2009. "A US Holy War? The Effects of Religion on Iraq War Policy Attitudes.” Social Science Quarterly 90 (1): 103-116. . 2014. "In the Valley of the Gun: Evangelical Christians, Warrior Culture, and Gun Culture in America." presented at the Annual Meeting of the Society for the Scientific Study of Religion, Indianapolis, Indiana, November 2.

Gallagher, Sally K., and Sabrina L. Wood. 2005. "Godly Manhood Going Wild?: Transformations in Conservative Protestant Masculinity." Sociology of Religion 66 (2): 135-59.

Gibson, David. 2012. “Is Gun Control a Religious Issue?” Washington Post. July 23. https://www.washingtonpost.com/national/on-faith/is-gun-control-a-religiousissue/2012/07/23/gJQAn4I94W_story.html.

Gielen, Andrea Carlson, David A. Sleet, and Lawrence W. Green. 2006. Injury and Violence Prevention: Behavior Change Theories, Methods and Applications. San Francisco, CA: Jossey-Bass.

Glass, Jennifer L., and J. Jacobs. 2005. "Childhood Religious Conservatism and Adult Attainment among Black and White Women.” Social Forces 84 (1): 555-79. 
Gollust, Sarah E., Jeff Niederdeppe, and Colleen L. Barry. 2013. "Framing the Consequences of Childhood Obesity to Increase Public Support for Obesity Prevention Policy." American Journal of Public Health 103 (11): e96-102.

Goodstein, Laurie. 2013. "Catholics Raise Issue of Guns Amid Call to End Abortion." The New York Times, January 25. http://www.nytimes.com/2013/01/26/us/politics/catholics-raiseissue-of-guns-amid-call-to-end-abortion.html.

Grasmick, Harold G., Robert J. Bursik Jr, and M 'lou Kimpel. 1991. "Protestant Fundamentalism and Attitudes toward Corporal Punishment of Children." Violence and Victims 6 (4): 283-93.

Grasmick, Harold G., Elizabeth Davenport, Mitchell B. Chamlin, and Robert J. Bursik. 1992. "Protestant Fundamentalism and the Retributive Doctrine of Punishment." Criminology 30 (1): 21-46.

Grasmick, Harold G., and Anne L. McGill. 1994. "Religion, Attribution Style, and Punitiveness Toward Juvenile Offenders." Criminology 32 (1): 23-46.

Greeley, Andrew, and Michael Hout. 2006. The Truth about Conservative Christians: What They Think and What They Believe. Chicago, IL: University of Chicago Press.

Gross, Neil, and Ethan Fosse. 2012. "Why Are Professors Liberal?" Theory and Society 41 (2): $127-68$.

Guyer, Bernard, Mary Anne Freedman, Donna M. Strobino, and Edward J. Sondik. 2000. "Annual Summary of Vital Statistics: Trends in the Health of Americans during the 20th Century." Pediatrics 106 (6): 1307-1317.

Harker, Kathryn. 2001. "Immigrant Generation, Assimilation, and Adolescent Psychological Well-Being." Social Forces 79 (3): 969-1004.

Hatch, Nathan O. 1989. The Democratization of American Christianity. New Haven: Yale University Press.

Hemenway, David. 2001. "The Public Health Approach to Motor Vehicles, Tobacco, and Alcohol, with Applications to Firearms Policy." Journal of Public Health Policy 22 (4): 381-402. doi:10.2307/3343157.

— 2011. "Risks and Benefits of a Gun in the Home." American Journal of Lifestyle Medicine 5 (6): 502-11.

Hemenway, David, Catherine Barber, and Matthew Miller. 2010. "Unintentional Firearm Deaths: A Comparison of Other-Inflicted and Self-Inflicted Shootings." Accident Analysis \& Prevention 42 (4): 1184-88.

Heston, Charlton. 1998. "Presidential Address." presented at the National Rifle Association, Philadelphia, PA.

Hill, Terrence D., Amy M. Burdette, Christopher G. Ellison, and Marc A. Musick. 2006. "Religious Attendance and the Health Behaviors of Texas Adults." Preventive Medicine 42 (4): 309-312.

Hill, Terrence D., Amy M. Burdette, Michael L. Weiss, and Dale D. Chitwood. 2009. "Religious Involvement and Adolescent Substance Use." In Adolescent Substance Abuse: EvidenceBased Approaches to Prevention and Treatment, edited by C. Leukefeld, T. Gullotta, and M. Staton-Tindall, 171-189. New York: Springer.

Hill, Terrence D., and Ryon J. Cobb. 2011. "Religious Involvement and Religious Struggles." In Toward a Sociological Theory of Religion and Health, edited by Anthony Blasi, 239-60. Boston: Brill. 
Hood, Ralph W., Peter C. Hill, and Paul W. Williamson. 2005. The Psychology of Religious Fundamentalism. New York: Guildford Press.

Hughes, Richard T. 2003. Myths America Lives By. Urbana, Ill.: University of Illinois Press.

Hughes, Richard T. 2009. Christian America and the Kingdom of God. Urbana, IL: University of Illinois Press.

Iannaccone, Lawrence R. 1994. "Why Strict Churches Are Strong.” American Journal of Sociology 99 (5): 1180-1211.

Jansson, Bjarne, Antonio Ponce De Leon, Niaz Ahmed, and Vibeke Jansson. 2006. "Why Does Sweden Have the Lowest Childhood Injury Mortality in the World? The Roles of Architecture and Public Pre-School Services.” Journal of Public Health Policy 27 (2): 146-65. doi:10.1057/palgrave.jphp.3200076.

Jiobu, Robert M., and Timothy J. Curry. 2001. "Lack of Confidence in the Federal Government and the Ownership of Firearms." Social Science Quarterly 82 (1): 77-88.

Johnson, David R., Christopher P. Scheitle, and Elaine Howard Ecklund. 2016. "Conservative Protestantism and Anti-Evolution Curricular Challenges Across States." Social Science Quarterly.

Kammen, Michael G. 2008. A Machine That Would Go of Itself: The Constitution in American Culture. New Brunswick, NJ: Transaction Publishers.

Katcher, M. L., A. N. Meister, C. A. Sorkness, A. G. Staresinic, S. E. Pierce, B. M. Goodman, N. M. Peterson, P. M. Hatfield, and J. A. Schirmer. 2006. "Use of the Modified Delphi Technique to Identify and Rate Home Injury Hazard Risks and Prevention Methods for Young Children." Injury Prevention 12 (3): 189-94.

Keister, Lisa A. 2008. "Conservative Protestants and Wealth: How Religion Perpetuates Asset Poverty." American Journal of Sociology 113 (5): 1237-1271.

Kellermann, A. L., and D. T. Reay. 1986. "Protection or Peril? An Analysis of Firearms Related Death in the Home." The New England Journal of Medicine 314: 1557-1560.

Kimmel, Michael, and Abby L. Ferber. 2000. "“White Men Are This Nation:' Right-Wing Militias and the Restoration of Rural American Masculinity." Rural Sociology 65 (4): 582-604. doi:10.1111/j.1549-0831.2000.tb00045.x.

Kleck, Gary, and Tomislav Kovandzic. 2009. "City-Level Characteristics and Individual Handgun Ownership Effects of Collective Security and Homicide." Journal of Contemporary Criminal Justice 25 (1): 45-66. doi:10.1177/1043986208329085.

Kozuskanich, Nathan R. 2009. "Pennsylvania, the Militia, and the Second Amendment." The Pennsylvania Magazine of History and Biography 133 (2): 119-47.

LaHaye, Tim. 1994. Faith of Our Founding Fathers. Green Forest, Arkansas: Master Books.

Land, Richard. 2007. "Reading between the Lines: Media Bias." Ethics and Religious Liberty Comission of the Southern Baptist Convention. https://erlc.com/article/reading-betweenthe-lines-media-bias.

Lee, Roberta K., Richard J. Waxweiler, James G. Dobbins, and Terri Paschetag. 1991. "Incidence Rates of Firearm Injuries in Galveston, Texas, 1979-1981." American Journal of Epidemiology 134 (5): 511-521.

Lehrer, Evelyn L. 1999. "Religion as a Determinant of Educational Attainment: An Economic Perspective." Social Science Research 28 (4): 358-79.

Leventhal, John M., Julie R. Gaither, and Robert Sege. 2014. "Hospitalizations due to Firearm Injuries in Children and Adolescents." Pediatrics 133 (2): 219-225. 
Loveland, Anne C. 1996. American Evangelicals and the U.S. Military, 1942-1993. Baton Rouge: Louisiana State University Press.

Manglos, Nicolette D. 2013. "Faith Pinnacle Moments: Stress, Miraculous Experiences, and Life Satisfaction in Young Adulthood." Sociology of Religion 74 (2): 176-98.

Marshall, Peter, and David Manuel. 1977. The Light and the Glory. Old Tappan, NJ: Fleming H. Revell.

Massengill, R. P. 2008. "Educational Attainment and Cohort Change Among Conservative Protestants, 1972-2004.” Journal for the Scientific Study of Religion 47 (4): 545-562.

Mazur, Allan. 2004. "Believers and Disbelievers in Evolution." Politics and the Life Sciences, 55-61.

McPherson, Miller, Lynn Smith-Lovin, and James M. Cook. 2001. "Birds of a Feather: Homophily in Social Networks." Annual Review of Sociology 27: 415-444.

Mencken, F. Carson, Christopher D. Bader, and Elizabeth Embry. 2009. "In God We Trust: Images of God and Trust in the United States among the Highly Religious." Sociological Perspectives 52 (1): 23-38.

Miller, Jon D., Eugenie C. Scott, and Shinji Okamoto. 2006. "Public Acceptance of Evolution." Science 313 (5788): 765-766.

Miller, Sharon Hodde. 2013. "Why All Christians Can Back Better Gun Control.” Christianity Today, January 9. http://www.christianitytoday.com/women/2013/january/why-allchristians-can-back-better-gun-control.html.

National Research Council. 2005. Firearms and Violence: A Critical Review. Washington, DC: National Academies Press.

Noll, Mark A. 1994. The Scandal of the Evangelical Mind. Grand Rapids, Mich.: W.B. Eerdmans.

NPR Staff. 2015. “An Evangelical Leader's Changing Views On Gun Ownership.” Npr.org. October 10. http://www.npr.org/2015/10/10/447250761/an-evangelical-leaders-changingviews-on-gun-ownership.

O’Connor, James F., and Alan Lizotte. 1978. "The 'Southern Subculture of Violence' Thesis and Patterns Of Gun Ownership." Social Problems 25 (4): 420-29.

Olson, Laura R. 2000. Filled with Spirit and Power: Protestant Clergy in Politics. Albany, N.Y.: SUNY Press.

Olson, Lynn M., Katherine K. Christoffel, and Karen G. O’Connor. 2007. “Pediatricians' Involvement in Gun Injury Prevention.” Injury Prevention 13 (2): 99-104.

Pearce, Lisa D., and Dana L. Haynie. 2004. "Intergenerational Religious Dynamics and Adolescent Delinquency." Social Forces 82 (4): 1553-72.

Perry, Samuel L., and Andrew L. Whitehead. 2015a. "Christian Nationalism and White Racial Boundaries: Examining Whites' Opposition to Interracial Marriage.” Ethnic and Racial Studies 38 (10): 1671-1689.

- 2015b. "Christian Nationalism, Racial Separatism, and Family Formation: Attitudes Toward Transracial Adoption as a Test Case." Race and Social Problems 7 (2): 123-134.

Pescosolido, Bernice A., and Sharon Georgianna. 1989. "Durkheim, Suicide, and Religion: Toward a Network Theory of Suicide." American Sociological Review 54 (1): 33-48.

Peterson, Jane, Jan R. Atwood, and Bernice Yates. 2002. "Key Elements for Church-Based Health Promotion Programs: Outcome-Based Literature Review." Public Health Nursing 19 (6): 401-411. 
Piper, John. 2015. "Should Christians Be Encouraged to Arm Themselves?" Desiring God. December 22. http://www.desiringgod.org/articles/should-christians-be-encouraged-toarm-themselves.

Plutzer, Eric, and Michael Berkman. 2008. "Trends Evolution, Creationism, and the Teaching of Human Origins in Schools." Public Opinion Quarterly 72 (3): 540-553.

Putnam, Robert D. 2000. Bowling Alone: The Collapse and Revival of American Community. New York: Simon \& Schuster.

Putnam, Robert D., and David E Campbell. 2010. American Grace: How Religion Divides and Unites Us. New York: Simon \& Schuster.

Regnerus, M. D. 2003. "Religion and Positive Adolescent Outcomes: A Review of Research and Theory." Review of Religious Research, 394-413.

Reinholt, Mia, Torben Pedersen, and Nicolai Foss. 2008. "Why an Attractive Network Isn't Enough: The Role of Motivation in Realizing Benefits from Knowledge Access." Center for Strategic Management and Globalization Working Paper. Copenhagen: Copenhagen Business School.

Richardson, Erin G., and David Hemenway. 2011. "Homicide, Suicide, and Unintentional Firearm Fatality: Comparing the United States With Other High-Income Countries, 2003:" The Journal of Trauma: Injury, Infection, and Critical Care 70 (1): 238-43.

Robertson, Pat. 1986. America's Dates with Destiny. Nashville, TN: Nelson.

Sandomirsky, Sharon, and John Wilson. 1990. "Processes of Disaffiliation: Religious Mobility among Men and Women." Social Forces 68 (4): 1211-1229.

Scheitle, Christopher P., and Amy Adamczyk. 2010. "High-Cost Religion, Religious Switching, and Health." Journal of Health and Social Behavior 51 (3): 325-42.

Schenck, Rob. 2016. "Should Christians Own Guns?” Sojourners, March 22.

Schieman, Scott, Tetyana Pudrovska, Leonard I. Pearlin, and Christopher G. Ellison. 2006. "The Sense of Divine Control and Psychological Distress: Variations Across Race and Socioeconomic Status." Journal for the Scientific Study of Religion 45 (4): 529-49.

Scott, Eugenie Carol. 2004. Evolution vs. Creationism: An Introduction. Berkeley, California: University of California Press.

Shenassa, Edmond D., Michelle L. Rogers, Kirsten L. Spalding, and Mary B. Roberts. 2004. "Safer Storage of Firearms at Home and Risk of Suicide: A Study of Protective Factors in a Nationally Representative Sample." Journal of Epidemiology and Community Health 58 (10): 841-848.

Sherkat, Darren E. 2010. "Religion and Verbal Ability." Social Science Research 39 (1): 2-13.

_. 2011. "Religion and Scientific Literacy in the United States." Social Science Quarterly. . 2012. "Religion and The American Occupational Structure." In Research in the Sociology of Work, edited by Lisa A Keister, John McCarthy, and Roger Finke, 23:75102. Bingley, United Kingdom: Emerald.

- 2016. "Religion, Politics, and Americans' Confidence in Science." Politics and Religion, August, 1-24. doi:10.1017/S1755048316000535.

Sherkat, Darren E., and Alfred Darnell. 1999. "The Effect of Parents' Fundamentalism on Children's Educational Attainment: Examining Differences by Gender and Children's Fundamentalism." Journal for the Scientific Study of Religion 38 (1): 23-35.

Sherkat, Darren E., and Christopher G. Ellison. 1997. "The Cognitive Structure of a Moral Crusade: Conservative Protestantism and Opposition to Pornography." Social Forces 75 (3): $957-80$. 
Sherkat, Darren E., and J. Wilson. 1995. "Preferences, Constraints, and Choices in Religious Markets: An Examination of Religious Switching and Apostasy." Social Forces 73 (3): 993-1026.

Sikkink, David. 1999. "The Social Sources of Alienation from Public Schools." Social Forces 78 (1): 51-86.

Sikkink, David, and Jonathan P. Hill. 2005. "Education." In Handbook of Religion and Social Institutions, 41-66. New York: Springer.

Simonetti, Joseph A., Jessica L. Mackelprang, Ali Rowhani-Rahbar, Douglas Zatzick, and Frederick P. Rivara. 2015. "Psychiatric Comorbidity, Suicidality, and In-Home Firearm Access Among a Nationally Representative Sample of Adolescents." JAMA Psychiatry 72 (2): 152-159.

Simpson, Brent. 2006. "The Poverty of Trust in the Southern United States." Social Forces 84 (3): 1625-1638.

Smith, Christian. 2000. Christian America?: What Evangelicals Really Want. Berkeley: University of California Press.

- 2003. "Theorizing Religious Effects among American Adolescents." Journal for the Scientific Study of Religion 42 (1): 17-30.

Smith, Christian, Michael O. Emerson, Sally Gallagher, Paul Kennedy, and David Sikkink. 1998. American Evangelicalism: Embattled and Thriving. Chicago: University of Chicago Press.

Smith, Greg, and A. Cooperman. 2015. “America’s Changing Religious Landscape.” Washington, DC: Pew Research Center.

Smith, Tom W. 1997. "Factors Relating to Misanthropy in Contemporary American Society." Social Science Research 26 (2): 170-196.

Smith-Lovin, Lynn, and J. Miller McPherson. 1993. "You Are Who You Know: A Network Approach to Gender." In Theory on Gender/feminism on Theory, edited by Paula England, 223-251. New York: Aldine de Gruyter.

Sorenson, Susan B., and Katherine A. Vittes. 2004. "Adolescents and Firearms: A California Statewide Survey." American Journal of Public Health 94 (5): 852-58.

Spilka, Bernard, Phillip Shaver, and Lee A. Kirkpatrick. 1985. "A General Attribution Theory for the Psychology of Religion.” Journal for the Scientific Study of Religion 24 (1): 1-20. doi:10.2307/1386272.

Stanojevich, Cristina. 2013. “Americans' Perspectives on the NRA.” PRRI. January 9. https://www.prri.org/spotlight/americans-perspectives-on-the-nra/.

Stark, Rodney, and Roger Finke. 2000. Acts of Faith: Explaining the Human Side of Religion. Berkeley: University of California Press.

Stark, Rodney, and Charles Y. Glock. 1969. "Prejudice and the Churches." In Prejudice U.S.A., edited by Charles Y. Glock and Ellen Siegleman, 70-95. New York: Preager.

Steensland, Brian, Jerry Z. Park, Lynn D. Robinson, W. Bradford Wilcox, and Robert D. Woodberry. 2000. "The Measure of American Religion: Toward Improving the State of the Art." Social Forces 79 (1): 291-318.

Stroope, Samuel. 2011a. "Education and Religion: Individual, Congregational, and Cross-Level Interaction Effects on Biblical Literalism." Social Science Research 40 (6): 1478-1493. - 2011b. "How Culture Shapes Community: Bible Belief, Theological Unity, and a Sense of Belonging in Religious Congregations.” The Sociological Quarterly 52 (4): 568-592. 
. 2012. "Social Networks and Religion: The Role of Congregational Social

Embeddedness in Religious Belief and Practice." Sociology of Religion 73 (3): 273-98.

Stroope, Samuel, Aaron B. Franzen, and Jeremy E. Uecker. 2015. "Social Context and College

Completion in the United States: The Role of Congregational Biblical Literalism."

Sociological Perspectives 58 (1): 120-37.

Thomson, Robert A., and Paul Froese. 2016. "God Versus Party: Competing Effects on Attitudes Concerning Criminal Punishment, National Security, and Military Service." Journal for the Scientific Study of Religion 55 (4): 839-58.

Thomson, Robert A., and Sung Joon Jang. 2016. "Homeschool and Underage Drinking: Is It More Protective than Public and Private Schools?" Deviant Behavior 37 (3): 281-301.

Trinitapoli, Jenny, Christopher G. Ellison, and Jason D. Boardman. 2009. "US Religious Congregations and the Sponsorship of Health-Related Programs." Social Science \& Medicine 68 (12): 2231-39.

Uecker, Jeremy E. 2014. "Religion and Early Marriage in the United States: Evidence from the Add Health Study." Journal for the Scientific Study of Religion 53 (2): 392-415.

Unnever, James D., Francis T. Cullen, and Brandon K. Applegate. 2005. "Turning the Other Cheek: Reassessing the Impact of Religion on Punitive Ideology." Justice Quarterly 22 (3): 304-39.

US Centers for Disease Control and Prevention. 2014. "Web-Based Injury Surveillance Query and Reporting System." http://www.cdc.gov/injury/wisqars/fatal.html.

Wallace, John M., and Tyrone A. Forman. 1998. "Religion's Role in Promoting Health and Reducing Risk among American Youth." Health Education \& Behavior 25 (6): 721-741.

Welch, Michael R., David Sikkink, and Matthew T. Loveland. 2007. "The Radius of Trust: Religion, Social Embeddedness and Trust in Strangers." Social Forces 86 (1): 23-46.

Westoff, Charles F., and Emily A. Marshall. 2010. "Hispanic Fertility, Religion and Religiousness in the U.S." Population Research and Policy Review 29 (4): 441-52.

Whitehead, Andrew L., and Samuel L. Perry. 2015. "A More Perfect Union? Christian Nationalism and Support for Same-Sex Unions." Sociological Perspectives 58 (3): 422440.

Wilcox, William Bradford. 2004. Soft Patriarchs, New Men: How Christianity Shapes Fathers and Husbands. University of Chicago Press.

Williams, David C. 1996. "The Militia Movement and Second Amendment Revolution: Conjuring with the People." Cornell Law Review 81 (4): 879-952.

Wuthnow, Robert. 1988. The Restructuring of American Religion: Society and Faith since World War II. Princeton, N.J.: Princeton University Press. . 2002. "Beyond Quiet Influence? Possibilities for the Protestant Mainline." In The Quiet Hand of God: Faith-Based Activism and the Public Role of Mainline Protestantism, edited by Robert Wuthnow and John Hyde Evans. Berkeley, California: University of California Press.

Yamane, David. 2016. "Awash in a Sea of Faith and Firearms: Rediscovering the Connection Between Religion and Gun Ownership in America." Journal for the Scientific Study of Religion 55 (3): 622-36. doi:10.1111/jssr.12282.

Zylstra, Sarah Eekhoff. 2013. "A New Creation Story: Why Do More Homeschoolers Want Evolution in Their Textbooks?" ChristianityToday, May. 
Table 1. Weighted descriptive statistics among US adolescents, Add Health (n $=18,449)^{\mathrm{a}}$

Firearm access

0.244

Religious tradition

Conservative Protestant $\quad 0.221$

Mainline Protestant $\quad 0.219$

Black Protestant $\quad 0.120$

Catholic $\quad 0.247$

Other religion $\quad 0.077$

Unaffiliated $\quad 0.128$

Female $\quad 0.493$

Age

15.450

Race/ethnicity

White non-Hispanic $\quad 0.651$

Black non-Hispanic $\quad 0.160$

Hispanic $\quad 0.069$

Other race non-Hispanic $\quad 0.120$

Southern residence $\quad 0.387$

Urbanicity

Urban $\quad 0.586$

Suburban $\quad 0.260$

Rural $\quad 0.154$

Biological/adoptive parent $\quad 0.544$

Parental education

Less than high school $\quad 0.139$

High school degree $\quad 0.228$

Some college $\quad 0.257$

College degree $\quad 0.279$

Greater than college degree $\quad 0.097$

Parental income $\quad 45.676$

${ }^{\mathrm{a}}$ Means and proportions are reported 
Table 2. Logistic regression of adolescents' easy access to a firearm at home, Add Health, $(\mathrm{n}=18,449)$

\begin{tabular}{|c|c|c|c|}
\hline & $\mathrm{b}$ & $\mathrm{SE}$ & $\mathrm{OR}^{\mathrm{a}}$ \\
\hline Intercept & $-1.08 * * *$ & 0.12 & \\
\hline \multicolumn{4}{|l|}{ Religious tradition } \\
\hline \multicolumn{4}{|c|}{ Conservative Protestant (reference) } \\
\hline Mainline Protestant & $-0.19 *$ & 0.09 & 0.83 \\
\hline Black Protestant & $-0.69 * * *$ & 0.17 & 0.50 \\
\hline Catholic & $-0.51 * * *$ & 0.10 & 0.60 \\
\hline Other religion & $-0.57 * * *$ & 0.13 & 0.56 \\
\hline Unaffiliated & $-0.47 * * *$ & 0.10 & 0.63 \\
\hline Female & $-0.74 * * *$ & 0.06 & 0.48 \\
\hline Age & $0.09 * * *$ & 0.02 & 1.09 \\
\hline \multicolumn{4}{|l|}{ Race/ethnicity } \\
\hline \multicolumn{4}{|c|}{ White non-Hispanic (reference) } \\
\hline Black non-Hispanic & $-0.67 * * *$ & 0.16 & 0.51 \\
\hline Hispanic & $-0.98 * * *$ & 0.13 & 0.38 \\
\hline Other race non-Hispanic & $-0.56 * * *$ & 0.13 & 0.57 \\
\hline Southern residence & $0.62 * * *$ & 0.11 & 1.86 \\
\hline \multicolumn{4}{|l|}{ Urbanicity } \\
\hline \multicolumn{4}{|l|}{ Urban (reference) } \\
\hline Suburban & $0.22 *$ & 0.10 & 1.25 \\
\hline Rural & $0.57 * *$ & 0.21 & 1.77 \\
\hline Biological /adoptive parent & $0.43 * * *$ & 0.06 & 1.55 \\
\hline \multicolumn{4}{|l|}{ Parental education } \\
\hline Less than high school & -0.15 & 0.10 & 0.86 \\
\hline \multicolumn{4}{|l|}{ High school degree (reference) } \\
\hline Some college & $0.31 * * *$ & 0.08 & 1.36 \\
\hline College degree & 0.07 & 0.08 & 1.07 \\
\hline Greater than college degree & -0.18 & 0.12 & 0.84 \\
\hline Parental income & $0.00^{\mathrm{b}}$ & 0.00 & 1.00 \\
\hline
\end{tabular}

$* P<.05 ; * * P<.01 ; * * * P<.001$ (two-tailed).

${ }^{a}$ Unstandardized coefficients, standard errors, and odds ratios reported.

${ }^{\mathrm{b}}$ This coefficient rounded to four decimal places is .0005 
Figure 1. Easy access to a firearm at home by religious tradition among adolescents, Add Health, $(n=18,449)$.

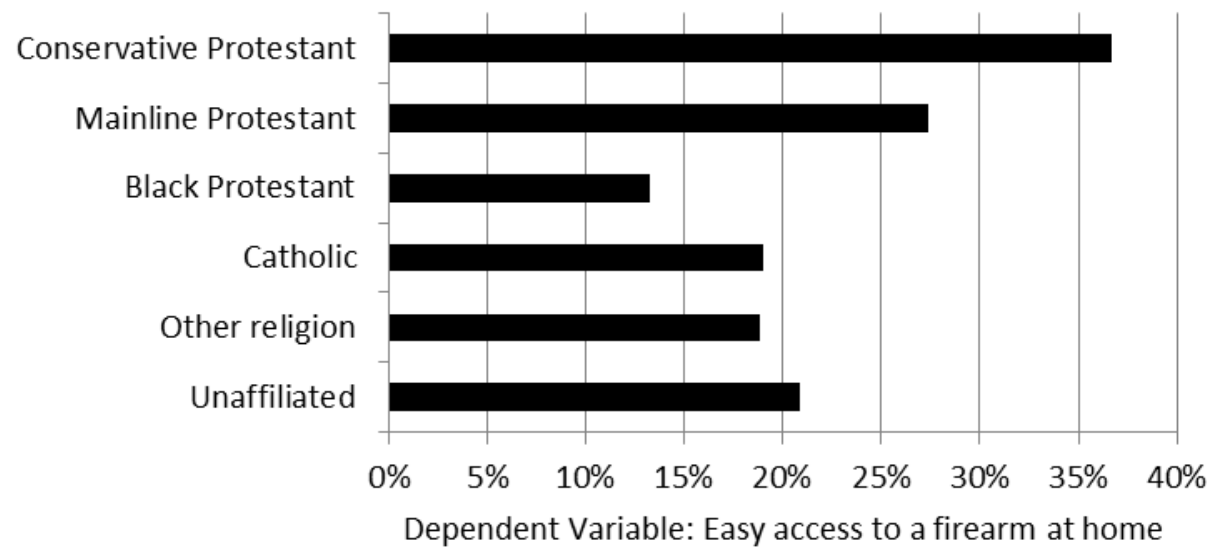

Figure 2. Probability of adolescents' easy access to a firearm at home by religious tradition, Add Health, $(n=18,449)$.

Conservative Protestant

Mainline Protestant

Black Protestant

Catholic

Other religion

Religiously unaffiliated

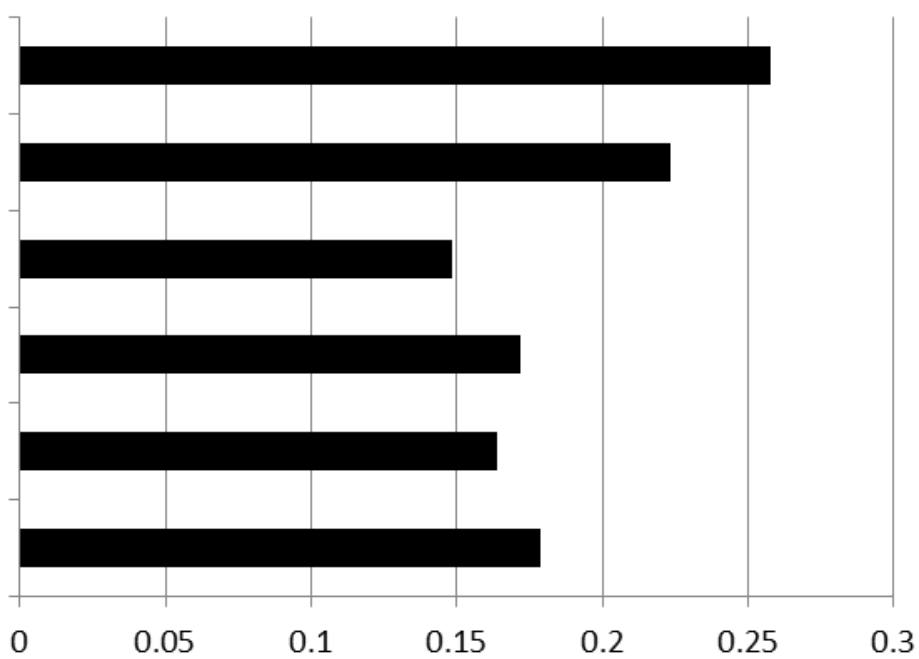

